\title{
Waste Willow-Bark from Salicylate Extraction Successfully Reused as an Amendment for Sewage Sludge Composting
}

\author{
Dorota Kulikowska * and Katarzyna Bernat
}

Department of Environmental Biotechnology, University of Warmia and Mazury in Olsztyn, 10-709 Olsztyn, Poland; bernat@uwm.edu.pl

* Correspondence: dorotak@uwm.edu.pl; Tel.: +48-89-523-4145; Fax: +48-89-523-4131

Citation: Kulikowska, D.; Bernat, K. Waste Willow-Bark from Salicylate Extraction Successfully Reused as an Amendment for Sewage Sludge Composting. Sustainability 2021, 13, 6771. https://doi.org/10.3390/ su13126771

Academic Editors: Alessio Siciliano and Chunjiang An

Received: 14 May 2021

Accepted: 8 June 2021

Published: 15 June 2021

Publisher's Note: MDPI stays neutra with regard to jurisdictional claims in published maps and institutional affiliations.

Copyright: (c) 2021 by the authors. Licensee MDPI, Basel, Switzerland. This article is an open access article distributed under the terms and conditions of the Creative Commons Attribution (CC BY) license (https:// creativecommons.org/licenses/by/ $4.0 /)$.

\begin{abstract}
Due to the fact that compost is a valuable fertilizer that serves principally as a source of macronutrients, composting is one of the preferred methods of management of organic waste, including municipal sewage sludge. However, due to its high moisture content and low $\mathrm{C} / \mathrm{N}$ ratio, sewage sludge cannot be composted alone. This study investigated the usefulness of waste willowbark (WWB) (after salicylate extraction) as an amendment for municipal sewage-sludge composting in a two-stage system: an aerated bioreactor and a periodically turned windrow. Both organic matter $(\mathrm{OM})$ removal and humification progress were monitored. It was found that the prepared feedstock (70\% sewage sludge, $25 \% \mathrm{WWB}$, and $5 \%$ wood chips, $w / w$ ) enabled proper temperature profiles to be obtained, with a maximum temperature of $72.3^{\circ} \mathrm{C}$. The rate constant of $\mathrm{OM}$ degradation in the bioreactor was $0.25 \mathrm{~d}^{-1}$, almost 4 -fold higher than that in the windrows. During composting, the concentrations of humic substances (HS), humic acids (HA), and the fulvic fraction (FF) changed. HS, HA, and FF formation proceeded according to 1 . order kinetics, and their respective rates were $1.33 \mathrm{mg} \mathrm{C/(g} \mathrm{OM} \mathrm{d),} 1.03 \mathrm{mg} \mathrm{C/(g} \mathrm{OM} \mathrm{d),} \mathrm{and} 0.76 \mathrm{mg} \mathrm{C/(g} \mathrm{OM} \mathrm{d).} \mathrm{However,} \mathrm{in} \mathrm{mature}$ compost, FF predominated (ca. 70\%) in HS. These results indicate that waste willow-bark, a product of salicylate extraction, can be successfully reused as an amendment during municipal sewage sludge composting. Both waste willow-bark reuse and sewage sludge composting are compatible with a circular economy.
\end{abstract}

Keywords: waste willow bark; composting; sewage sludge; organic matter; humic substances; humic acids; fulvic fraction

\section{Introduction}

Due to increasing global demand for organic matter and macronutrients (e.g., nitrogen, phosphorous, and other macronutrients, such as potassium and sulphur), organic wastes, including sewage sludge, are considered rich available resources. Therefore, one of the important strategies in sewage sludge management is its utilization to reclaim soil or to fertilize agricultural soils. However, due to the possible presence of pathogens, sewage sludge should be appropriately treated before it is applied to the soil, e.g., by composting, during which thermophilic conditions destroy pathogens.

It is commonly known that compost principally serves as a source of macronutrients. However, it must be stressed that mature compost may be rich in stable organic matter (humic substances, HS). Therefore, applying compost to soil enables carbon to be sequestered in the form of stable organic matter; maintaining and increasing the level of soil organic carbon is one of the key goals in the priorities of the European Union's Thematic Strategy for Soil Protection. From that point of view, it is extremely important to analyze humification progress and HS content in mature compost.

A literature review and our previous studies and experience indicate that humification progress depends on feedstock composition, particularly the content and type of lignocellulosic materials, as well as temperature conditions during composting. If the composting 
feedstock contains a relatively high content of lignin, this may accelerate the formation of stable HS. This phenomenon is connected with the fact that the phenols that are released during partial lignin degradation serve as precursors for HS formation [1].

Kulikowska, Klimiuk [2] investigated the dependence between HS formation and the share of rape straw and grass in municipal sewage sludge composting. They showed that the feedstock composition affected the temperature conditions (with rape straw, thermophilic conditions were obtained; with grass, the maximal temperature did not exceed $43-44{ }^{\circ} \mathrm{C}$ ). These factors also affected the rate of organic matter mineralization and the formation of HS, especially humic acids (HA). Those authors showed that the temperature during composting was the main factor affecting polymerization of fulvic acids (FA) to $\mathrm{HA}$ and that the polymerization degree increased only when thermophilic conditions were obtained during composting. In consequence, the content of HA in mature compost from sewage sludge with rape straw equalled $90.86 \mathrm{mg} \mathrm{C} / \mathrm{g} \mathrm{OM}$, ca. four times higher than that in compost from sewage sludge amended with grass. Zhao et al. [3] analyzed the impact of the type of crop straws (rape straw, wheat straw, maize straw, and rice straw) in the feedstock on HS content in compost (during 45 days of processing). They showed that, compared to initial concentrations in the feedstocks, the concentrations of HS and HA in the composts increased by $32.2 \%$ and $112 \%$, respectively, with rape straw; by $45.9 \%$ and $139 \%$, respectively, with wheat straw; by $54.4 \%$ and $170 \%$, respectively, with maize straw; and by $51.9 \%$ and $161 \%$, respectively, with rice straw. Maize straw and rice straw had higher hemicellulose contents, which caused larger increases in HS and HA content; while rape straw and wheat straw had higher lignin contents, which caused more moderate humification. Other authors also stated that adding the proper amendments to feedstock plays an essential role in humification progress [4].

White willow (Salix alba) is the main natural source of salicylic acid. The tree contains salicylic glycosides, which are biologically active. Salicylates are extracted from willow bark, usually in liquid-liquid systems with limited miscibility. After extraction, solid residues in the form of fine needle-like particles are obtained. Spanic et al. [5] have reported that the mean amounts of willow wood components are $2.0 \%$ extractives, $54.0 \%$ cellulose and $26.3 \%$ lignin. Bodirlau et al. [6] found similar values of $2.68 \%$ hot-water extractives, $50.59 \%$ cellulose, $23.45 \%$ lignin and $0.91 \%$ ash. Additionally, Stolarski et al. [7] reported finding $41.7 \%$ cellulose, $26.7 \%$ hemicelluloses, and $24.5 \%$ lignin. As lignocellulosic materials are desirable for humification, willow bark seems to be an appropriate component for feedstock in sewage sludge composting. According to authors' best knowledge, waste willow-bark after salicylate extraction has not been used for that purpose.

We hypothesized that waste willow-bark after salicylate extraction is a useful amendment for municipal sewage sludge composting. As it is known that a high HS content in soil has some advantages (it improves field water capacity, air capacity, soil porosity, and permeability), it is important to analyze the content of HS in compost. Moreover, from a practical point of view (for process design), data on the rate of organic matter mineralization and humification are extremely important. These data on mineralization and humification kinetics allow estimation of the retention time of feedstock in the bioreactor and the maturation time in the windrow. Therefore, the aim of this study was to determine the kinetic constants of organic matter mineralization and humification during sewage sludge composting with waste willow-bark as an amendment. Particular attention was given to establishing the rates of organic matter degradation and humification (considered as the rates of HS, HA, and fulvic fraction (FF) formation), and the concentrations of HS, $\mathrm{HA}$, and FF in mature compost.

\section{Materials and Methods}

\subsection{Feedstock}

Sewage sludge was taken from a municipal wastewater treatment plant operating with a sequencing batch reactor (SBR system) in north-eastern Poland. Due to its high moisture, low porosity and high nitrogen content, which are reflected by a low $\mathrm{C} / \mathrm{N}$ ratio, 
sewage sludge cannot be composted alone. To improve sewage sludge properties, different lignocellulosic materials are added. In this study, waste willow bark (after salicylate extraction) (WWB) was used for the first time. The waste willow-bark was obtained from a local small chemical plant (north-east Poland). It was in the form of fine needle-like particles no longer than $2 \mathrm{~cm}$ (Figure 1). Air-dried WWB was used as a component for feedstock preparation.

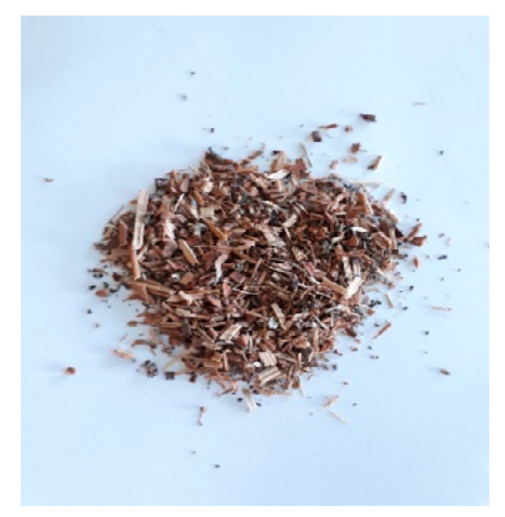

Figure 1. Waste willow-bark after salicylate extraction.

The feedstock composition was as follows: $70 \%(w / w)$ municipal sewage sludge after dewatering, 25\% WWB $(w / w)$, and 5\% wood chips ( $(w / w)$. The addition of wood chips lowered moisture content and improved the structure of the feedstock; the addition of WWB also improved the $\mathrm{C} / \mathrm{N}$ ratio. The characteristics of the composting materials and the feedstock are presented in Table 1. In the sewage sludge, Salmonella spp. and eggs of Ascarsis, Trichuris or Toxocara spp. were not found.

Table 1. Characteristics of the composting components and feedstock.

\begin{tabular}{cccccc}
\hline \multirow{2}{*}{ Characteristics } & \multirow{2}{*}{ Units } & \multicolumn{4}{c}{ Components/Feedstock } \\
\cline { 3 - 6 } & & Sewage Sludge & WWB & Wood Chips & Feedstock \\
\hline Moisture & $(\%)$ & $85.2 \pm 1.7$ & $16.1 \pm 0.3$ & $26.1 \pm 0.7$ & $67 \pm 1.8$ \\
OM & $(\%$ DM) & $89.2 \pm 1.4$ & $93.2 \pm 3.1$ & $97.1 \pm 1.9$ & $90.2 \pm 1.4$ \\
TN & $(\%$ DM) & $5.64 \pm 0.3$ & $1.83 \pm 0.04$ & $0.98 \pm 0.02$ & $3.2 \pm 0.04$ \\
TOC & $(\%$ DM) & $42.1 \pm 1.3$ & $54.1 \pm 1.7$ & $52.3 \pm 1.9$ & $46.7 \pm 0.9$ \\
OM/N & - & 15.8 & 50.9 & - & 28.2 \\
C/N & - & 7.46 & 29.6 & - & 14.6 \\
\hline
\end{tabular}

\subsection{Composting Mode}

The composting process was conducted in a two-stage system, i.e., an aerated bioreactor with a volume of $100 \mathrm{dm}^{3}$ (1st stage) and a periodically turned windrow (2nd stage).

Air was supplied via a ventilator to the perforated floor on the bottom of the bioreactor. In order to prevent feedstock overheating, the aeration intensity was monitored and maintained in the range of 0.5 to $1.5 \mathrm{~L} /(\mathrm{kg} \cdot \mathrm{min})$. The bioreactor was equipped with temperature sensors situated at depths of $30 \mathrm{~cm}$ and $70 \mathrm{~cm}$ below the upper cover of the bioreactor.

The composting process lasted 140 days. When the feedstock temperature dropped below $30^{\circ} \mathrm{C}$ after 21 days of decomposition of organics and sanitation in the bioreactor, the composted material was moved to the windrow. However, due to the fact that the moisture content remained high, the windrow was turned twice a week at the beginning, then the turning frequency was limited to once a week. Maturation in the windrow lasted 120 days. 


\subsection{Analytical Methods}

In the dewatered sludge, WWB and wood chips, the contents of moisture, dry mass $(\mathrm{DM})$, organic matter $(\mathrm{OM})$, and total nitrogen $(\mathrm{TN})$ were determined. This was used to determine the proportion of the components in the feedstock.

Samples of the feedstock and those taken during the composting process were collected in accordance with the Polish standard PN-Z-15011-1, described in detail in Kulikowska, Sindrewicz [4]. All samples were dried at $105^{\circ} \mathrm{C}$ to determine their dry mass, and then ground to a diameter of $0.5 \mathrm{~mm}$ (using a Retsch SM 100 mill). Organic matter was determined as loss by ignition at $550{ }^{\circ} \mathrm{C}$ (PN-Z-15011-3:2001), and total N, by the Kjeldahl method (PN-Z-15011-3:2001).

Municipal sewage sludge was analyzed for the presence of Salmonella spp., and eggs of Ascarsis, Trichuris and Toxocara spp. These analyses were done in a dedicated Laboratory of Microbiology and Parasitology, according to the Polish standard PN-EN ISO/IEC 17025:2005.

During composting, HS, and their fractions, i.e., FF and HA, were analyzed. The detailed procedure has been described in Kulikowska, Klimiuk [2]. Briefly, to remove soluble substances, which are mostly sugars and proteins, compost samples were washed three times with distilled water. Then, to remove bitumen and waxes, extraction with a mixture of chloroform and methanol at a ratio of 2:1 was performed. The extractions were carried out in a MarsXpress microwave oven $\left(60^{\circ} \mathrm{C} ; 10 \mathrm{~min}\right)$ until a colorless supernatant was obtained. For extraction of $\mathrm{HS}, 0.1 \mathrm{M} \mathrm{NaOH}$ at $\mathrm{pH} 12$ was applied. Then, the filtrate was acidified to $\mathrm{pH} 1$ with $\mathrm{H}_{2} \mathrm{SO}_{4}$. The obtained precipitate (HA) was allowed to coagulate for $24 \mathrm{~h}$ at $4{ }^{\circ} \mathrm{C}$. $\mathrm{HA}$ and $\mathrm{FF}$ were separated by centrifugation. HA were resuspended in $0.1 \mathrm{M} \mathrm{NaOH}$, and then TOC in the HS and HA was determined (Shimadzu Liquid TOC-VCSN analyzer). The FF were determined by subtracting the content of HA from that of HS.

\section{Results and Discussion}

\subsection{Temperature Profiles and Organic Matter Removal}

During composting in the bioreactor, the $\mathrm{pH}$ and temperature were monitored. Initially, both of these parameters rapidly increased, which is a characteristic of the process (Figure 2). The temperature increase depends on the mineralization of readily available substrates, which releases energy that is accumulated in the form of heat. In this study, mesophilic conditions were reached after ca. $50 \mathrm{~h}$ and thermophilic conditions, after ca. $60 \mathrm{~h}$. The maximum temperature in the upper layer of the composted feedstock was $66.4{ }^{\circ} \mathrm{C}$ (top of the reactor), and in the middle layer, it was $72{ }^{\circ} \mathrm{C}$ (center of the reactor) (Figure 2a).

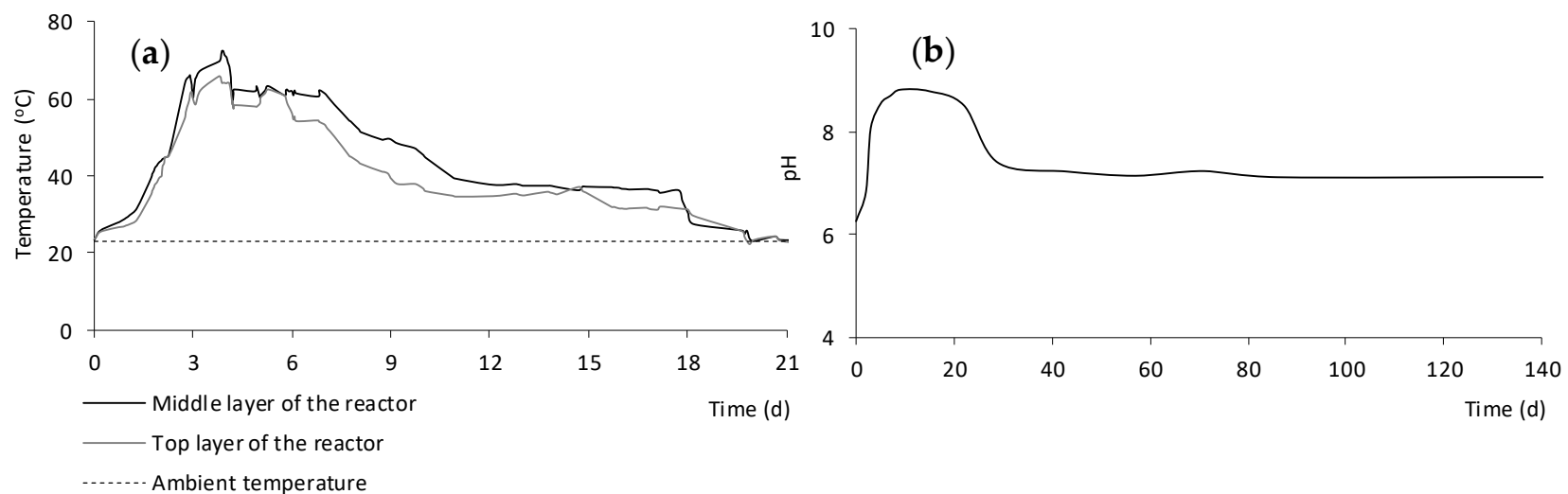

Figure 2. Temperature profiles in the middle and top layers of the reactors (a) and changes in the values of $\mathrm{pH}(\mathbf{b})$ during composting. 
This increase in temperature was caused by intense mineralization of easily degradable organic compounds. Thermophilic conditions lasted ca. 4 and 5 days in the upper and middle layers of the feedstock, respectively. The maximum temperature and the length of the thermophilic phase depend not only on the content of readily biodegradable organics, but also on the $\mathrm{C} / \mathrm{N}$ ratio in the feedstock. However, it must be emphasized that, in laboratory scale reactors, the duration of the thermophilic phase is shorter than in technical scale reactors. This is typical in laboratory conditions, and it results from the much smaller mass of the composted feedstock (much smaller bioreactor volume), and, thus, the smaller amount of readily available substrates. For example, Ucaroglu, Alkan [8] analyzed temperature profiles during composting of sewage sludge with wheat straw (R1), plane leaf (R2), corncob (R3), and sunflower stalk (R4). Those authors showed that, in R3 and $\mathrm{R} 4$, the thermophilic phase was very short: the temperature in $\mathrm{R} 3$ remained above $40{ }^{\circ} \mathrm{C}$ for 8 days and $18 \mathrm{~h}$, during which temperatures higher than $55^{\circ} \mathrm{C}$ were maintained only for 2 days and $10 \mathrm{~h}$. Similarly, the temperature in $\mathrm{R} 4$ remained above $40{ }^{\circ} \mathrm{C}$ for 5 days and $11 \mathrm{~h}$, and a temperature of more than $55^{\circ} \mathrm{C}$ was maintained for $22 \mathrm{~h}$. In contrast, in both $\mathrm{R} 1$ and $\mathrm{R} 2$, the temperatures never reached $55^{\circ} \mathrm{C}$. As mentioned, the amount of available easily biodegradable organic matter affects the temperature in all reactors, and corncob and sunflower stalk have a higher content of easily biodegradable organic matter than wheat straw and plane leaf.

It should be emphasized that the $\mathrm{C} / \mathrm{N}$ ratio in the feedstock may also affect the length of the thermophilic phase, but opinions differ in regard to this. For example, Bustamante et al. [9], during composting exhausted grape marc with cattle manure (C/N 20.2) and exhausted grape marc with poultry manure $(\mathrm{C} / \mathrm{N}$ 13.1) in an aerated windrow, showed that the length of thermophilic phase at a $\mathrm{C} / \mathrm{N}$ ratio of 20.2 lasted 76 days. However, at a $\mathrm{C} / \mathrm{N}$ ratio of 13.1 , it was 1.6 -fold longer (122 days). $\mathrm{C} / \mathrm{N}$ values did not affect the maximal process temperature $\left(53-55^{\circ} \mathrm{C}\right)$. This would mean that lowering the $\mathrm{C} / \mathrm{N}$ ratio in the composted feedstock favors the extension of the thermophilic phase. Huang et al. [10], however, obtained different results. Those authors composted manure with sawdust. At a $\mathrm{C} / \mathrm{N}$ ratio of 30 , thermophilic conditions were obtained after 3 days, the maximal temperature was $69{ }^{\circ} \mathrm{C}$, and the thermophilic phase lasted 40 days. At a $\mathrm{C} / \mathrm{N}$ ratio of 15 , thermophilic conditions were obtained after 7 days, the maximal temperature was lower, $60{ }^{\circ} \mathrm{C}$, and the thermophilic phase lasted 32 days. According to the authors, the decrease in maximal temperature and the shortened thermophilic phase resulted from insufficient carbon content in the feedstock at the lower $\mathrm{C} / \mathrm{N}$ ratio. In our study, however, the relatively short thermophilic phase may have resulted from two causes: the small mass of the feedstock in the laboratory-scale reactor, and, thus, the smaller amount of readily available substrates, as well as the low $\mathrm{C} / \mathrm{N}$ ratio (14.6).

In the initial phase of composting, an increase in $\mathrm{pH}$ was observed (Figure $2 \mathrm{~b}$ ). This was related to the mineralization of nitrogen-containing organic compounds and the release of ammonia, and then the $\mathrm{pH}$ decreased as a result of nitrification (data not shown).

During composting of sewage sludge with WWB and wood chips, organic matter (OM) content decreased due to mineralization. Mineralization of OM proceeded according to 1. order kinetics both in the bioreactor and the windrow. The kinetics of OM mineralization were calculated using Equation (1):

$$
\mathrm{OM}_{\text {mineralization }}=A \cdot \mathrm{e}^{-k \mathrm{OM} \cdot t}
$$

where: $A$ is the maximal loss in OM content ( $\mathrm{g} \mathrm{OM} / \mathrm{kg} \mathrm{DM}), k_{\mathrm{OM}}$ is the rate constant of OM mineralization, and $t$ is the composting time $(\mathrm{d})$. The rate of the OM mineralization $\left(r_{\mathrm{OM}}\right)$ can be calculated as the product of $A$ and $k_{\mathrm{OM}}$.

In two-stage systems for composting that consist of closed bioreactors and windrows, $\mathrm{OM}$ mineralization is expected to be more intensive in the controlled conditions of the bioreactor due to higher availability of easily biodegradable compounds at the beginning phase of composting. In the windrow, the rate of OM mineralization is lower, and mainly transformations of the components of the OM (i.e., HS) take place. 
In the bioreactor, the rate constant of OM removal $\left(k_{\mathrm{OM}}\right)$ was $0.25 \mathrm{~d}^{-1}$, which was more than 4-times higher than in the windrow $\left(0.06 \mathrm{~d}^{-1}\right)$ (Figure 3a,b). Zhao et al. [3], during composting of sewage sludge with rape, wheat, maize, or rice straw, reported lower values of the rate constant of OM degradation than those in the present study, ranging from $0.056 \mathrm{~d}^{-1}$ with maize straw to $0.084 \mathrm{~d}^{-1}$ with rice straw. It is known that the constant rates of organic matter removal depend both on the type of substrates (feedstock composition) and technological conditions during composting. The lowest values of the rate constants of mineralization were noted during composting feedstock with lignocellulosic materials [11,12]. Therefore, some authors, to accelerate degradation of lignocellulosic, use inoculation, e.g., with fungi producing non-specific laccase [13]. Laccases enhance the efficiency of of phenolic and non-phenolic compounds including lignin. The high $k_{\mathrm{OM}}$ value in this study $\left(0.25 \mathrm{~d}^{-1}\right)$, however, could result from the fact that feedstock contained sewage sludge with relatively high biodegradable organics and waste willow-bark that was subject to some kind of pre-treatment due to salicylate extraction.
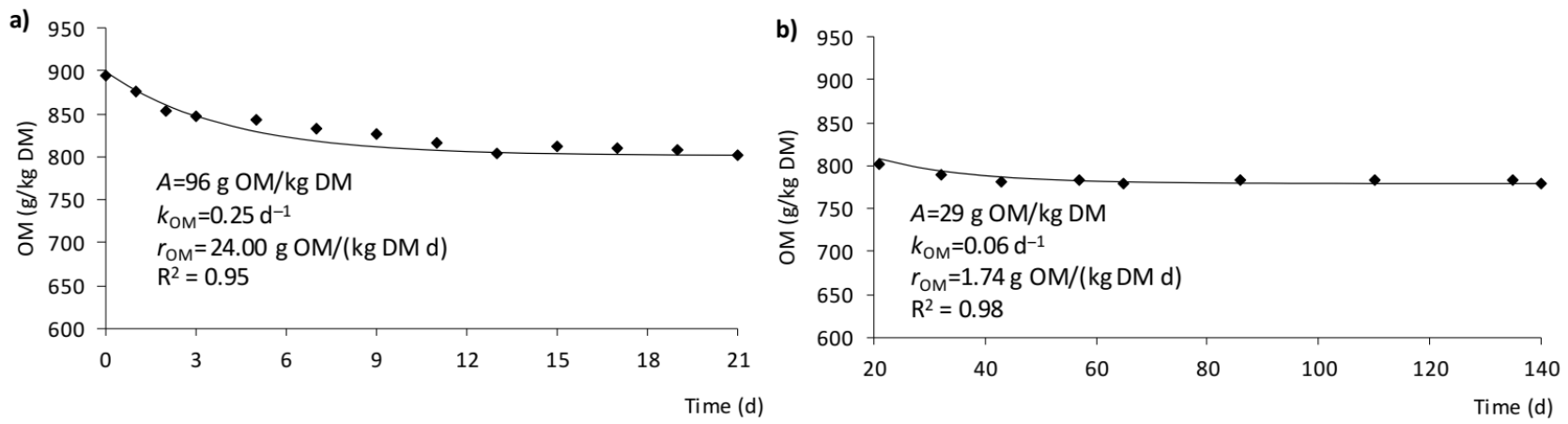

Figure 3. Changes in the organic matter (OM) content during composting in the reactor (a) and in windrow (b); kinetic parameters are given, the maximal decrease in OM mineralized during the composting process (A), the rate constant of OM mineralization $\left(k_{\mathrm{OM}}\right)$, and the rate of the decrease in $\mathrm{OM}\left(r_{\mathrm{OM}}\right)$.

In the bioreactor, the maximal decrease in the $\mathrm{OM}(A)$ was $96 \mathrm{~g} / \mathrm{kg} \mathrm{DM}$, whereas $r_{\mathrm{OM}}$ (rate of OM mineralization) was $24.0 \mathrm{~g} /(\mathrm{kg} \mathrm{DM} \cdot \mathrm{d})$. In the windrow the kinetic constants were lower: $29 \mathrm{~g} / \mathrm{kg} \mathrm{DM}(A)$ and $1.74 \mathrm{~g} /(\mathrm{kg} \mathrm{DM} \cdot \mathrm{d})\left(r_{\mathrm{OM}}\right)$.

In this study, both temperature profile and effective removal of organic, clearly indicate that retention time in the bioreactor during composting sewage sludge with waste-willowbark as amendment, was properly designed.

The goal of composting sludge from wastewater treatment plants is to utilize as much sludge as possible. This means that the process should proceed with the highest content of sewage sludge possible, at least $60 \%$ of the wet mass of feedstock (or ca. $30 \%$ on a dry mass basis). In the study reported here, the share of sewage sludge was $70 \%$ of the total wet mass, which was $29.6 \%$ of DM. This share of sewage sludge enabled a proper moisture content $(67 \%)$ to be obtained, but due to the relatively high nitrogen content in the sewage sludge, the organics to nitrogen ratios were relatively low (OM/N was $28.2 ; \mathrm{C} / \mathrm{N}$ was 14.6). Therefore, it was not possible to increase the share of sewage sludge, which caused the amount of biodegradable organics to be relatively small and the thermophilic phase to be comparatively short.

\subsection{OM Humification}

Analysis of humification progress during composting is important because humic substances (HS) content is considered to be a factor that improves the quality of compost. The importance of HS for soil fertility and structure, and the positive effects of HS on plant growth are commonly known. In this study, HS, HA and FF were analyzed and the kinetics of humification (HS, HA and FF formation) were calculated from Equation (2):

$$
C=C_{\max } \cdot\left(1-\mathrm{e}^{-k \cdot t}\right)+C_{\mathrm{i}}
$$


where: $C(\mathrm{mg} \mathrm{C} / \mathrm{g} \mathrm{OM})$ is the concentration of HS, HA or FF over time; $C_{\max }(\mathrm{mg} \mathrm{C} / \mathrm{g} \mathrm{OM})$ is the maximal increase in the concentration of $\mathrm{HS}\left(C_{\max , \mathrm{HS}}\right), \mathrm{HA}\left(C_{\max , \mathrm{HA}}\right)$ or $\mathrm{FF}\left(C_{\max , \mathrm{FF}}\right)$ during composting; $k\left(\mathrm{~d}^{-1}\right)$ is the rate constant of $\mathrm{HS}\left(k_{\mathrm{HS}}\right)$, HA $\left(k_{\mathrm{HA}}\right)$ or FF $\left(k_{\mathrm{FF}}\right)$ formation; $t$ is the composting time $(\mathrm{d})$; and $C_{\mathrm{i}}(\mathrm{mg} \mathrm{C} / \mathrm{g} \mathrm{OM})$ is the concentration of HS, HA, or FF in the feedstock.

In the feedstock, the concentration of HS was high (123.8 mg C/g OM) (Figure 4a), due to the relatively high share of sewage sludge. In the HS, FF predominated $(107.2 \mathrm{mg} \mathrm{C} / \mathrm{g}$ $\mathrm{OM}, 86.6 \%$ ) (Figure 4c). During composting, the content of all fractions of HS increased: the contents of HS and HA increased to $190.2 \mathrm{mg} \mathrm{C} / \mathrm{g} \mathrm{OM}$ and $59.3 \mathrm{mg} \mathrm{C/g} \mathrm{OM}$, respectively (Figure $4 a, b$ ). The contents of HS and HA are generally reported to increase during different types of waste composting. However, Zhou et al. [14] reported that HS content decreased during 60 days of composting food waste, sawdust and Chinese medicinal herbal residues. According to those authors, this phenomenon resulted from a marked decrease in FF content. Other authors have observed a decrease in FA content, but an increase in HA content [15-18]. In the present study, however, the FF content increased from $107.2 \mathrm{mg} \mathrm{C} / \mathrm{g}$ $\mathrm{OM}$ to $133.2 \mathrm{mg} \mathrm{C} / \mathrm{g}$ OM. However, it must be emphasized that FF formation started only on the 70th day of the process (Figure 4c). The lack of changes in FF content before the 70th day may have resulted from two causes: polymerization of FF to HA (which was strongly suggested by a marked increase in degree of polymerization, DP; Figure 5a), and possibly, microbial degradation of FF. Shin et al. [19] reported biodegradation of FF in drinking water in small-scale biofilm reactors. According to those authors, FF oxidation should have provided the carbon and energy for long-term biofilm growth and maintenance as the FF was the only electron donor in the feed. Although their study was conducted with water, not compost, their results indicate that FF biodegradation is possible. Moreover, although HS degradation during composting is not a typical phenomenon, it is known that some species of fungi and actinomycetes can degrade HS [20-23]. For example, Doherter, Blondeau [22] analyzed the impact of extracellular lignin peroxidase and Mn-dependent peroxidase activities of two white rot fungi, Phanerochaete chrysosporium and Trametes versicolor on HA biodegradation. Those authors showed that although both P. chrysosporium and $T$. versicolor have the ability to HA degrade, $T$. versicolor was a more effective HA degrader than $P$. chrysosporium. Fungi decompose HS due to the action of extracellular enzymes, and they degrade HS more effectively than actinomycetes [24].

Based on the changes in HS, HA and FF concentrations, the kinetic parameters of humification were calculated. Formation of both HS and their fractions (HA and FF) proceeded with 1. order kinetics (Figure $4 \mathrm{a}-\mathrm{c}$ ). The kinetic constant of HS formation was $0.018 \mathrm{~d}^{-1}$, whereas those of HA and FF formation were $0.027 \mathrm{~d}^{-1}$. The rate of HS formation was $1.33 \mathrm{mg} \mathrm{C} /(\mathrm{g} \mathrm{OM} \cdot \mathrm{d})$, while those of HA and FF formation were lower, equaling 1.03 and $0.76 \mathrm{mg} \mathrm{C} /(\mathrm{g} \mathrm{OM} \cdot \mathrm{d})$, respectively. The increase in the concentration of HA from the beginning of the composting process may indicate intensive polymerization of FF to HA, as also evidenced by changes in DP values (Figure 5a). DP is a measure of the formation of complex molecules of HA from simpler molecules of fulvic acids. In this study, the DP values increased from 0.19 to 0.45 . The low value of DP in the feedstock indicates that, in the HS in the sewage sludge, FF predominated. The more than 2 -fold higher DP values in the mature compost indicate polymerization of FF to HA. However, despite this polymerization, the DP values remained below 1, and in the mature compost, FF predominated in the HS (ca. 70\% of HS) (Figure 5b). 

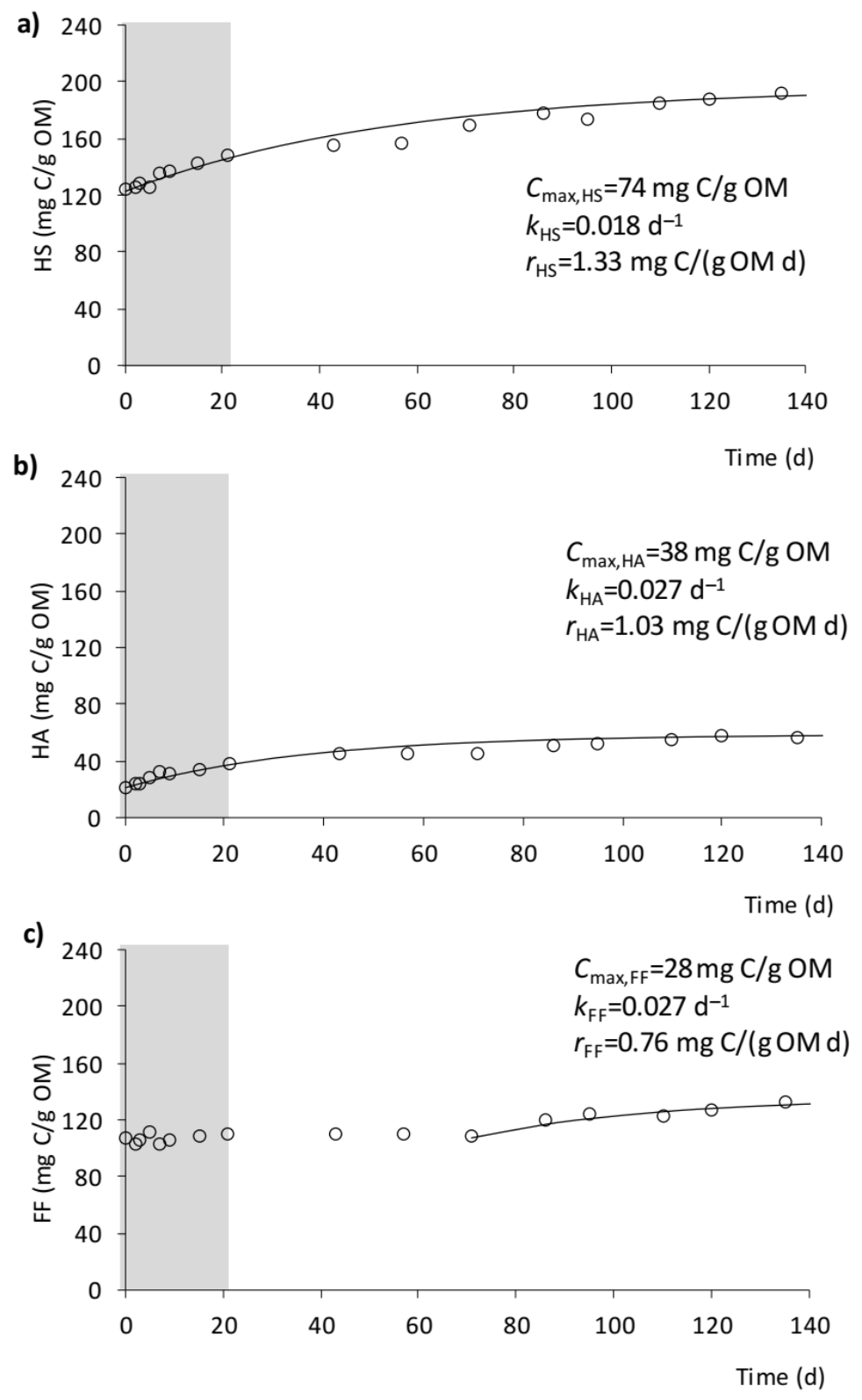

Figure 4. Changes in the concentration of HS (a), HA (b), and FF (c) during composting; kinetic parameters are given, maximal increase in concentration of $\mathrm{HS}\left(C_{\max , \mathrm{HS}}\right), \mathrm{HA}\left(C_{\max , \mathrm{HA}}\right)$ and FF $\left(C_{\mathrm{max}, \mathrm{FF}}\right)$, the rate constant of $\mathrm{HS}\left(k_{\mathrm{HS}}\right), \mathrm{HA}\left(k_{\mathrm{HA}}\right)$ or FF $\left(k_{\mathrm{FF}}\right)$ formation, the rate of $\mathrm{HS}\left(r_{\mathrm{HS}}\right), \mathrm{HA}$ $\left(r_{\mathrm{HA}}\right)$ or $\mathrm{FF}\left(r_{\mathrm{FF}}\right)$ formation; the grey areas indicate the time of composting in the reactor.

Some authors indicated that humification progress may be accelerated by biochar addition. Jindo et al. [25] analyzed the impact of biochar (B) on DP value during poultry manure (PM) and cow manure (CM) composting. Those authors showed that the biochar addition caused higher DP value during both PM and CM composting. For example, in mature PM compost, DP equaled ca. 2.1 and in PM + B compost it was higher (ca. 2.5). These values are much higher than in present study (0.45), however it must be emphasized that in the study of Jindo et al. [25], the DP values were high also in the feedstock (ca. 1.0). Other authors also showed positive impact of biochar on humification progress. Wang et al. [26] showed that feedstock (pig manure with sawdust) amended with biochar gave higher HA carbon content (by 16.9\%) than that without biochar. According to authors, higher O-alkyl C/alkyl C ratio and aromaticity and peak intensities of fulvic-like and humic-like substances was achieved faster in samples amended with biochar indicated that biochar amendment intensified the humification of pig manure. 

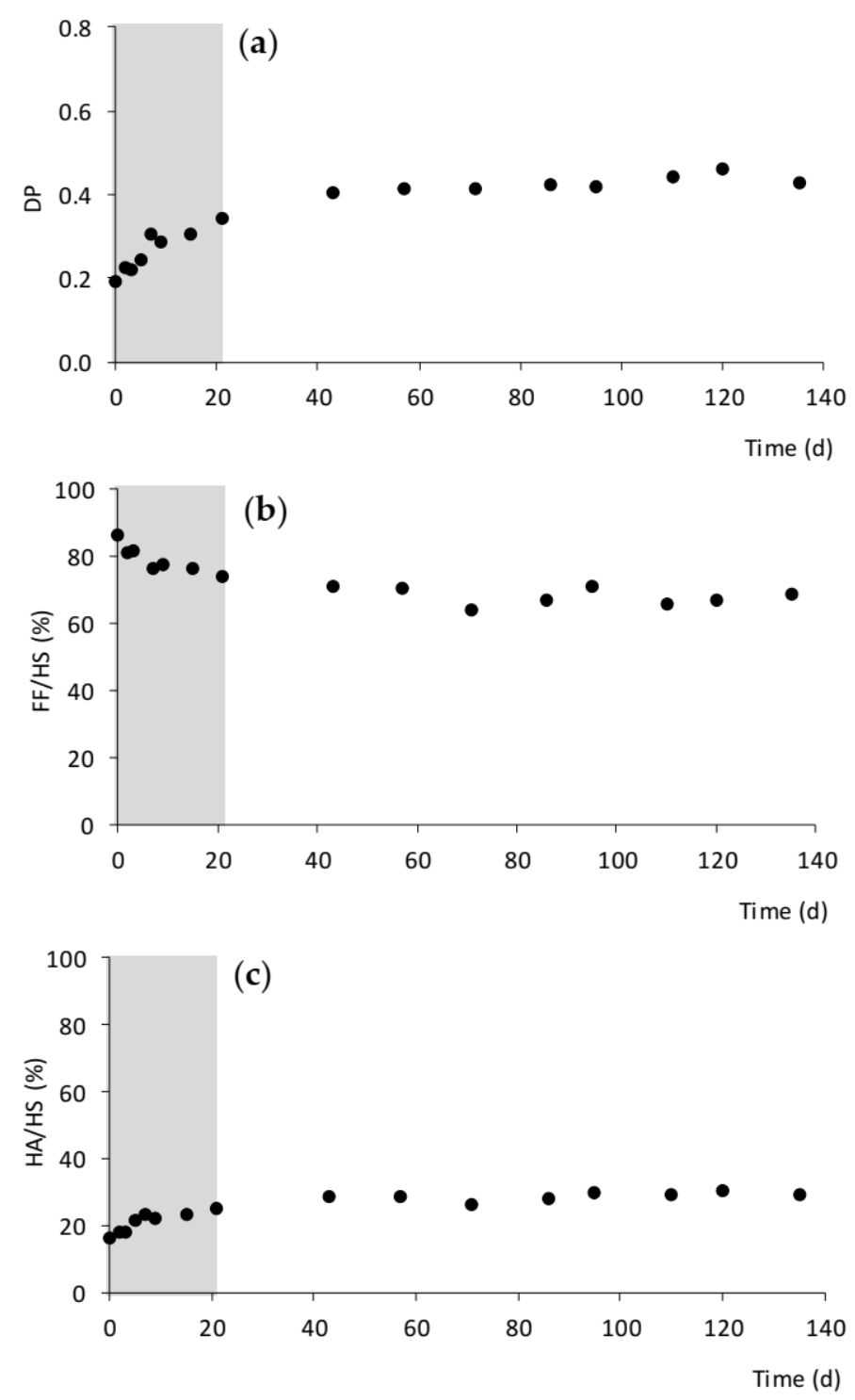

Figure 5. The degree of polymerization (DP) (a), the share of FF in HS (FF/HS) (b) and the share of HA in HS (HA/HS) (c) during composting, the grey areas indicate the time of composting in the reactor.

A predominance of FF in HS is not a typical phenomenon, but it is also observed when using bark as an amendment. In our previous study [4], comparing sewage sludge composting with straw and with coniferous bark, we found that, although the increase in HS concentration during composting was higher with bark than with straw (178 $\mathrm{mg} \mathrm{C} / \mathrm{g}$ OM vs. $84 \mathrm{mg} \mathrm{C/g} \mathrm{OM),} \mathrm{FF} \mathrm{predominated} \mathrm{in} \mathrm{HS} \mathrm{when} \mathrm{bark} \mathrm{was} \mathrm{used} \mathrm{(80 \% ),} \mathrm{whereas} \mathrm{HA}$ predominated when straw was used $(82 \%)$.

\section{Conclusions}

In congruence with the precepts of a circular economy, waste should be treated as a resource. Sewage sludge contains a high content of organics and macronutrients, and, therefore, can be used in agriculture to fertilize or reclaim soil. However, before soil application, it must be subjected to appropriate treatments, e.g., composting. The high humidity and low $\mathrm{C} / \mathrm{N}$ ratio of sewage sludge make it necessary to add other organic material for successful composting. In this study sewage sludge was amended with WWB and wood chips (70\% sewage sludge, $25 \%$ WWB, and 5\% wood chips, $w / w)$. The results presented here, particularly the appropriate temperature profiles with thermophilic conditions and with a maximum temperature of $72.3^{\circ} \mathrm{C}$, the effective removal of organics 
(with the rate of OM mineralization in the bioreactor of $24 \mathrm{~g} \mathrm{OM} /(\mathrm{kg} \mathrm{DM} \cdot \mathrm{d})$ and $1.71 \mathrm{~g}$ $\mathrm{OM} /(\mathrm{kg} \mathrm{DM} \cdot \mathrm{d})$ in the windrow), and the satisfactory progress of humification (HS content in mature compost of $190.2 \mathrm{mg} \mathrm{C} / \mathrm{g} \mathrm{OM}$ and the humification rate of $1.33 \mathrm{mg} \mathrm{C} /(\mathrm{g} \mathrm{OM} \cdot \mathrm{d}))$, indicate that waste willow bark can be successfully reused as an amendment for sewage sludge composting.

Author Contributions: Conceptualization, D.K.; methodology, K.B. and D.K.; formal analysis, K.B. and D.K.; investigation, K.B. and D.K.; data curation, D.K.; writing — original draft preparation, K.B. and D.K.; writing-review and editing, K.B. and D.K.; visualization, K.B.; supervision, D.K. All authors have read and agreed to the published version of the manuscript.

Funding: We are grateful for the financial support of the Ministry of Science and Higher Education, Poland (statutory project No. 29.610.024-110). Publication (Open Access) of this research was financially co-supported by Minister of Science and Higher Education in the range of the program entitled "Regional Initiative of Excellence" for the years 2019-2022, Project No. 010/RID/2018/19, amount of funding 12,000,000 PLN.

Institutional Review Board Statement: Not applicable.

Informed Consent Statement: Not applicable.

Data Availability Statement: Not applicable.

Conflicts of Interest: The authors declare no conflict of interest.

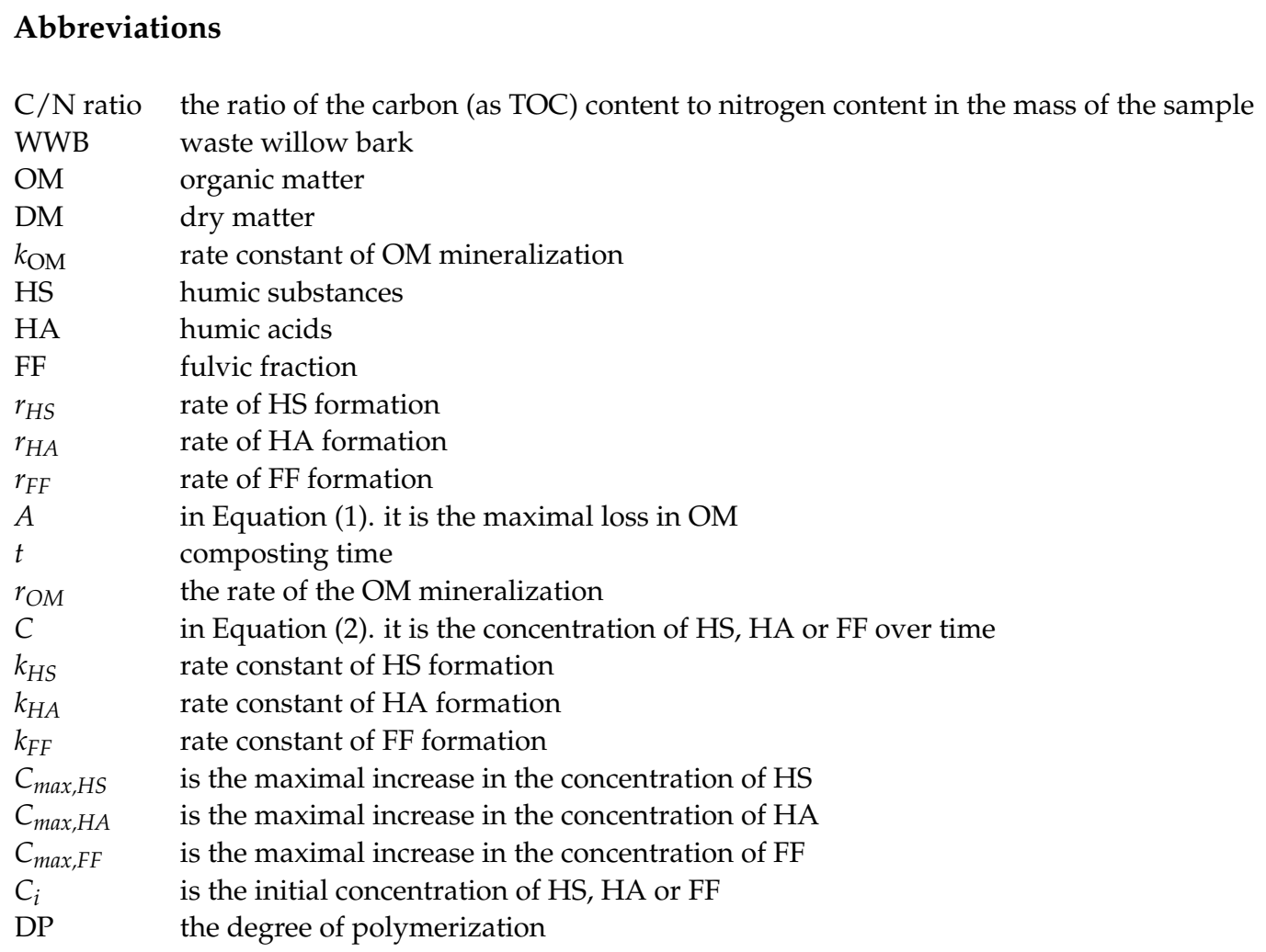

\section{References}

1. Sánchez-Monedero, M.A.; Roig, A.; Cegarra, J.; Bernal, M.P. Relationships between water-soluble carbohydrate and phenol fractions and the humification indices of different organic wastes during composting. Bioresour. Technol. 1999, 70, $193-201$. [CrossRef]

2. Kulikowska, D.; Klimiuk, E. Organic matter transformations and kinetics during sewage sludge composting in a two-stage system. Bioresour. Technol. 2011, 102, 10951-10958. [CrossRef] [PubMed]

3. Zhao, X.-L.; Li, B.-Q.; Ni, J.-P.; Xie, D.-T. Effect of four crop straws on transformation of organic matter during sewage sludge composting. J. Integr. Agric. 2016, 15, 232-240. [CrossRef] 
4. Kulikowska, D.; Sindrewicz, S. Effect of barley straw and coniferous bark on humification process during sewage sludge composting. Waste Manag. 2018, 79, 207-213. [CrossRef] [PubMed]

5. Spanic, N.; Jambrekovic, V.; Medved, S.; Antonovic, A. Chemical and thermal properties of cellulose acetate prepared from white willow (Salix alba) and black alder (Alnus glutinosa) as a potential polymeric base of biocomposite materials. Chem. Biochem. Eng. Q. 2015, 29, 357-365. [CrossRef]

6. Bodirlau, R.; Spiridon, I.; Teaca, C.A. Chemical investigation on wood tree species in a temperate forest, east-northern Romania. BioResources 2007, 2, 41-57. [CrossRef]

7. Stolarski, M.J.; Szczukowski, S.; Tworkowski, J.; Wróblewska, H.; Krzyżaniak, M. Short rotation willow coppice biomass as an industrial and energy feedstock. Ind. Crops Prod. 2011, 33, 217-223. [CrossRef]

8. Uçaroğlu, S.; Alkan, U. Composting of wastewater treatment sludge with different bulking agents. J. Air Waste Manag. 2016, 66, 288-295. [CrossRef]

9. Bustamante, M.A.; Paredes, C.; Marhuenda-Egea, F.-C.; Pérez-Espinoza, A.; Bernal, M.P.; Moral, R. Co-composting of distillery with animal manures: Carbon and nitrogen transformations in the evaluation of compost stability. Chemosphere 2008, 72, 551-557. [CrossRef]

10. Huang, G.F.; Wong, J.W.C.; Wu, Q.T.; Nagar, B.B. Effect of C/N on composting of pig manure with sawdust. Waste Manag. 2004, 24, 805-813. [CrossRef]

11. García-Gómez, A.; Roig, A.; Bernal, L.P. Composting of the solid fraction of olive mill wastewater with olive leaves: Organic matter degradation and biological activity. Biores. Technol. 2003, 86, 59-64. [CrossRef]

12. Alburquerque, J.A.; Gonzálvez, J.; Tartosa, G.; Baddi, G.A.; Cegarra, J. Evaluation of “alperujo" composting based on organic matter degradation, humification and compost quality. Biodegradation 2009, 20, 257-270. [CrossRef]

13. Fersi, M.; Mbarki, K.; Gargouri, K.; Mechichi, T.; Hachicha, R. Assessment of organic matter biodegradation and physico-chemical parameters variation during co-composting of lignocellulosic wastes with Trametes trogii inoculation. Environ. Eng. Res. 2019, 24 670-679. [CrossRef]

14. Zhou, Y.; Selvam, A.; Wong, J.W. Evaluation of humic substances during co-composting of food waste, sawdust and Chinese medicinal herbal residues. Bioresour. Technol. 2014, 168, 229-234. [CrossRef]

15. Veeken, A.; Nierop, K.; Wilde, V.; Hamelers, B. Characterization of $\mathrm{NaOH}$ extracted humic acids during composting of a biowaste. Bioresour. Technol. 2000, 72, 33-41. [CrossRef]

16. Paredes, C.; Bernal, M.P.; Cegarra, J.; Roig, A. Biodegradation of olive mill wastewater sludge by its co-composting with agricultural wastes. Bioresour. Technol. 2002, 85, 1-8. [CrossRef]

17. Domeizel, M.; Khalil, A.; Prudent, P. UV spectroscopy: A tool for monitoring humification and for proposing an index of the maturity of compost. Bioresour. Technol. 2004, 94, 177-184. [CrossRef]

18. Jouraiphy, A.; Amir, S.; Gharous, M.; Revel, J.-C.; Hafidi, M. Chemical and spectroscopic analysis of organic matter transformation during composting of sewage sludge and green plant waste. Int. Biodeter. Biodegr. 2005, 56, 101-108. [CrossRef]

19. Shin, H.S.; Lim, K.H. Spectroscopic and elemental investigation of microbial decomposition of aquatic fulvic acid in biological process of drinking water treatment. Biodegradation 1996, 7, 287-295. [CrossRef]

20. Martin, J.P.; Haider, K. Microbial degradation and stabilization of 14C-labeled lignins, phenols, and phenolic polymers in relation to soil humus formation. In Lignin Biodegradation: Microbiology, Chemistry and Applications; Higuchi, T., Chang, H.M., Eds.; CRC Press: Boca Raton, FL, USA, 1980; Volume 1, pp. 77-100.

21. Tuomela, M.; Vikman, M.; Hatakka, A.; Itävaara, M. Biodegradation of lignin in a compost environment: A review. Biores. Technol. 2000, 72, 169-183. [CrossRef]

22. Dehorter, B.; Blondeau, R. Extracellular enzyme activities during humic acids degradation by the white rot fungi Phanerochate chrysosporium and Trametes versicolor. FEMS Microbiol. Lett. 1992, 94, 209-215. [CrossRef]

23. Kästner, M.; Hofrichter, M. Biodegradation of humic substances. In Biopolymers, V.1-Lignin, Humic Substances and Coal; Steinbüchel, A., Hofrichter, M., Eds.; Wiley-VCH: Weinheim, Germany, 2001; pp. 349-378.

24. Kontchou, C.Y.; Blondeau, R. Biodegradation of soil humic acids by Streptomyces viridosporus. Can. J. Microbiol. 1992, 38, $203-208$. [CrossRef] [PubMed]

25. Jindo, K.; Sonoki, T.; Matsumoto, K.; Canellas, L.; Roig, A.; Sanchez-Monedero, M. Influence of biochar addition on the humic substances of composting manures. Waste Manag. 2016, 49, 545-552. [CrossRef] [PubMed]

26. Wang, C.; Tu, Q.; Dong, D.; Strong, P.J.; Wang, H.; Sun, B.; Wu, W. Spectroscopic evidence for biochar amendment promoting humic acid synthesis and intensifying humification during composting. J. Hazard. Mater. 2014, 280, 409-416. [CrossRef] 